VIKTOR ILIEVSKI

UDC: 115:141.131(38)

Skopje

Macedonia

\title{
ETERNITY AND TIME IN PLATO'S TIMAEUS
}

\begin{abstract}
This article explores the concepts of eternity and time as employed by Plato in his metaphysics and natural philosophy. It focuses on the Timaeus, which is the main source used in the attempts to reconstruct Plato's theory of time and to gain insights into his understanding of time's paradigm and counterpart, i.e. eternity. The chief thesis regarding Plato's concept of eternity presented here is that Plato conceived of it not as infinite duration (sempiternity), but as timeless, unchanging present (eternity proper). It thus, in accordance with the original meaning of the Greek term for eternity ( $\left.\alpha i^{\prime} \omega v\right)$, signifies the state of being of the Forms. As far as time ( $\chi \rho \operatorname{có}_{\mathrm{v}} \varsigma$ ) and its nature is concerned, an attempt is made here to argue that Plato did not identify time with a) the heavenly sphere in motion, b) number, nor with c) motion in general, motion of the heavenly sphere, or motion of some of its part -as suggested by some ancient, as well as contemporary commentators. In fact, time is inseparable from motion, however not as being motion, but as being characterized by regular motion, through which it enlivens the world of Becoming and makes it what it is. So it turns out that Plato's somewhat poetic description of time as moving image of eternity is more than just a metaphorical expression - eternity, the state of being of the Forms, reflects itself into time, the never-ending-life of the universe in constant motion. Time, as every image, has to be imperfect and therefore, unlike its paradigm, entails permanent change and instability.
\end{abstract}

The Platonic story of the interrelation of time and eternity is briefly related in the Timaeus 37c-38c. Therein appears Plato's famous definition of time, which stands in relation to eternity as its "eternal image that moves according to number" ( $\kappa \alpha \tau^{\prime} \alpha \dot{\alpha} \rho t \theta \mu$ òv

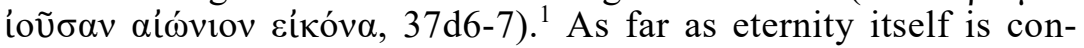
cerned, put in the plainest way possible, Plato speaks of it primarily in relation with the sphere of Being, i.e. the Forms; the attribute

${ }^{1}$ The translations from Greek (in Burnet, Ioannes (ed.). Platonis Opera Tomus IV. Oxonii, 1962) are mine, unless noted otherwise. The translations of the Latin authors are from the works cited in the Bibliography. 
'eternal' is most properly predicated of them. ${ }^{2}$ A Form is the foremost eternal entity, that which "always is, having no becoming"

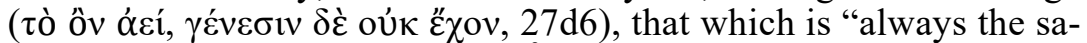

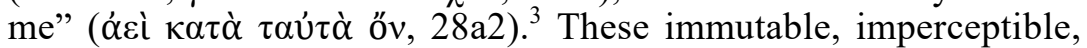
imperishable, eternal entities inhabit the intelligible realm, and are contrasted with the transient sensible objects belonging to the physical world, which never truly is, but always undergoes the process

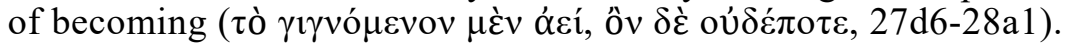

Although this account seems rather straightforward and unproblematic, there is nevertheless a catch - both terminological and conceptual one. The point is that in the foregoing passages of the Timaeus Plato ascribes to the Forms what we call 'eternity'

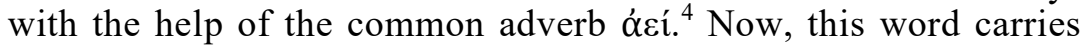
obvious temporal meaning, is often used with other words that refer to time, and thus signifies duration. On the other hand, many ancient authors, as well as contemporary scholars, embrace the concept of timeless, non-durational present as the only true referent of the term eternity. ${ }^{5}$ Any infinity with temporal suggestions, i.e. infinite duration - regardless of whether unlimitedly extended

${ }^{2}$ As Mohr (2005, p. 52) has it: "These assignations ['eternal', 'permanent', 'immutable'] are so frequent and so central to Plato's understanding of Forms that they come to stand ... as periphrastic designations of the Forms themselves ... close to being technical expressions for Plato."

${ }^{3}$ See also Phaedo $78 \mathrm{c}-\mathrm{d}$.

${ }^{4}$ Whittaker (1968, p. 136, n. 11) provides a non-exhaustive list of passages in the dialogues where ócí is used in reference to the Forms.

${ }^{5}$ Such an understanding of eternity was explicitly argued for by Plotinus (see Enn. III.7.6). He was adamant that Plato as well had held the same view, and defined eternity ( $\alpha \dot{i} \omega v$ ) as "immutable life of Being which is around the One" (III.7.6.8). The subsequent Neo-Platonists followed suit, as did St. Augustine and "the last of the Romans," Boethius. Proclus not only understood eternity non-temporally (see Sorabji 1983, p. 115), but also hypostatized and deified it, locating it within the first principle of the triad Being-Life-Intellect, which belongs to the hypostasis of nous (for a thorough exposition of Proclus's standpoint on eternity and time, see O'Neill 1962). In his Confessions, St. Augustine described eternity as "[e]ver-fixed" (Confessions, XI.11.13, in Shedd 1867), and everpresent (XI.13.16), and explained that "[i]n the Eternal nothing passeth, but the whole is present; whereas no time is all at once present" (XII.11.13). Boethius, in a Plotinian fashion, defined eternity as "[c]omplete, simultaneous and perfect possession of everlasting life" (Cons. Phil. V.6, p. 163, in Watts 1969), and also wrote: "[t]hat which embraces and possesses simultaneously the whole fullness of everlasting life, which lacks nothing of the future and has lost nothing of the past, that is what may properly be said to be eternal" (op. cit., p. 164). For a modern rebuttal of the opinion that the ancient and medieval thinkers held to a durational concept of eternity, as well as a defense of the durationless view, see Rogers 1994. For a succinct synopsis of the ancient and medieval positions, as well as of the modern debate regarding the atemporal and temporal understanding of eternity in theology, see Helm 2014. 
in both directions, or having a beginning but not an end - is more properly called everlastingness, or sempiternity. ${ }^{6}$ In this regard arises the question of Plato's position on the issue. Is he using the word ócí in atemporal or temporal sense, and, consequently, is he eternalist or sempiternalist? There is no easy, or even straightforward answer to this question, and, expectedly, the opinions of the scholars are divided. Cherniss (1944, pp. 211-213), W. Kneale (1960-1961, pp. 92-94), Owen (1966), M. Kneale (1968-1969, pp. 224f), Tarán (1979), Zeyl (2000, p. xlii), among others, are in favor of the atemporal reading; Cornford (1997 (1937), p. 102) and Whittaker (1968), among others, hold that Plato conceived of eternity as durational infinity, i.e. as sempiternity, while Sorabji concludes that "Plato did not decide between making eternity timeless and giving it everlasting duration." ${ }^{7}$ Whittaker's is the greatest effort invested in arguing that Plato lacked the concept of eternity proper and that he ascribed to his Forms an existence of temporal everlastingness. He founds his thesis mostly on the fact that Plato

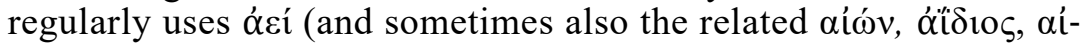
ẃvios) indiscriminately of the Forms, of Becoming, of $\psi v \chi \eta$, of oú-

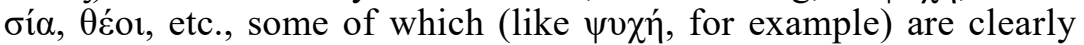
temporal, albite also intransient, entities. However, what he actually manages to prove, as it seems to me, is only that Plato's ó $\varepsilon i$, etc., can and often indeed do bear temporal meanings - but not that it is excluded that those words may also express timeless eternity, ${ }^{8}$ which they in fact also do. This is true at least for the Timae$u s$, as it will be shown in a moment. Plato is, after all, notorious

${ }^{6}$ M. Kneale (1968-1969, p. 223) writes: : “A sempiternal object is one which exists at all moments of time." But see op. cit. for a relativization of the difference between eternity and sempiternity. Boethius does not falter: "Whatever, therefore, suffers the condition of being in time, even though it never had any beginning, never has any ending and its life extends into the infinity of time ... it is still not such that it may properly be considered eternal" (Cons. Phil. V.6, p. 164). An ancient champion of the concept of sempiternity (in the sense of unlimited infinite duration) is arguably Aristotle. For an argument that even Aristotle's god is sempiternal, see Sorabji 1983, pp. 125-127. Cf. W. Kneale (19601961, pp. 102ff) and von Leyden 1964.

${ }^{7}$ Sorabji 1983, p. 112.

${ }^{8}$ Very telling in this regard is Whittaker's otherwise well-argued treatment of the Phaedo 79a6-11 and the argument attached to it (1968, pp. 133ff). Therein Plato draws a contrast between the invisible (i.e. eternal) and visible (i.e. transi-

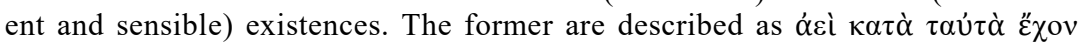

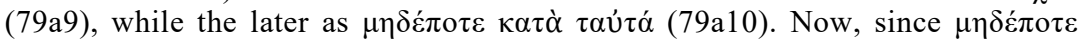
(never) has obvious temporal meaning, Whittaker concludes that the preceding

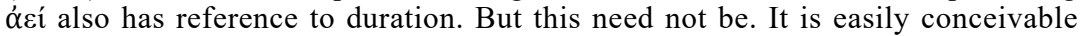
that somebody may say, although somewhat imprecisely, that "God always abides in eternity, a state which nothing created can ever approach," without being prevented (by the usage of the temporal 'ever') from intimately holding that God enjoys timeless eternity. 
for his terminological inaccuracies - and one example here should suffice - it is sometimes not ease to discern what he refers to when using the famous words $\varepsilon \tilde{\delta} \delta o \zeta$ and i $\delta \varepsilon \dot{\varepsilon} \alpha$ : ideal Form, i.e. an archetype, a universal, species or kind. ${ }^{9}$

Nevertheless, it is a fact that Plato's language is confusing, and that nobody can deny. The problem persists with the introduction of the aforementioned noun $\alpha i \omega$ v, by many later Platonists understood as referring to eternity proper, and itself taken to be derived from $\alpha \varepsilon \varepsilon^{10}{ }^{10}$ Plotinus, for example, who considered himself a faithful Platonist and but a commentator clarifying those sometimes obscure words of the Master, clearly took $\alpha i$ ív to mean timeless eternity. However, that is far from being the primary, even the traditional meaning of the word. At the contrary, in Homer it meant 'life, lifespan, lifetime', and was thus sometimes coupled with $\psi v \chi \eta$; in this context it also meant 'spinal marrow'. ${ }^{11}$ Again, very unlike the sense it acquires with the Neoplatonists, it was used to refer to a delineated, limited portion of time, a given epoch, but in this regard also to a very long time span, and only later, by further extension of meaning, to eternity. ${ }^{12}$ The Greek philosophers, both those predating Plato and some of those who came after him, were no exception: "The Presocratic philosophers used it as a term for lastingness or long, even infinitely long, duration" ${ }^{13}$, while Aristotle was almost certainly using the word aíw in the sense of sempi-

${ }^{9}$ E.g. the Socratic universals in the early dialogues, and $\varepsilon \tilde{\delta} \delta$ o $\varsigma=$ species (Tim. 37e 4, 83c3). This tendency towards terminological inaccuracy is not idiosyncratic to Plato: it was prevalent among the Greeks at least till the appearance of the great systematizer Aristotle. When it comes to ócí, the first recorded disambiguation is in Plotinus' Ennead III.7.2.28-29 and III.7.6.22-36 (for a comment on Plotinus' concept of non-temporal eternity, see Sorabji 1983, pp. 112114). The distinction of different senses was canonized by Proclus, who said that $\alpha \varepsilon^{\prime}$ has one meaning when used with reference to time, another when used with

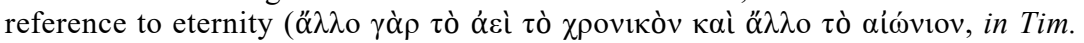
73c, quoted in Cherniss 1944, p. 420, n. 351)

${ }^{10}$ As far as the etymology of $\alpha i \omega v$ is concerned, Aristotle explains that it has

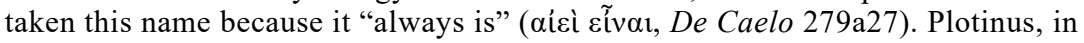

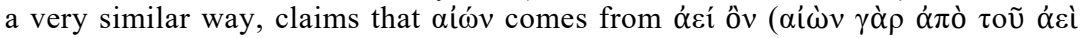

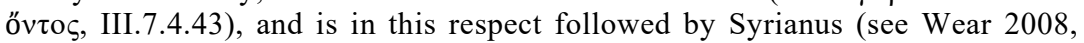
649). For a thoroughly different etymology of $\alpha i \omega ́ v$, see Onians 1951, p. 209.

11 "[T] his word originally meant the spinal marrow, which was held to be in a special way the vehicle of a creature's life." (M. Kneale, 1968-1969, p. 223).

${ }^{12}$ For more meanings and further detail, see the $L S J$ entry on $\alpha i \omega v$. For the history of the development of the different senses of aív, from life-fluid through spinal marrow and lifetime to eternity, see the learned exposition in Onians 1951, pp. 200-228 (esp. 200-209).

${ }^{13}$ von Leyden 1964, p. 36 
ternity. ${ }^{14}$ But then, what about Plato? In which sense did he use

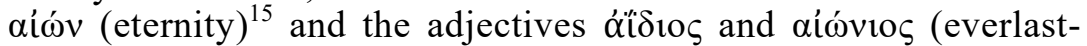
ing, eternal), the last of which was most probably introduced by himself? Or, in other words, what would 'eternity' mean to Plato? The answer to this query is to be found in a seminal passage of the Timaeus, dealing both with time and eternity (37c6-38a8):

When the begetting Father perceived it thus set in motion and liv-

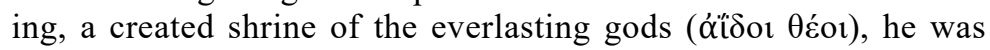
delighted, and thus filled with joy he thought of making it even more similar to the paradigm. So, just as the paradigm was an ev-

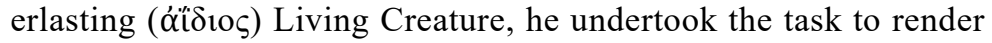
also this universe such, to the extent that was possible. Now the

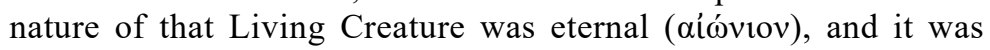
certainly not possible to bestow that fully upon the begotten. Instead, he started to think of making a moving image of eternity ( $\alpha i \dot{\omega} v$ ), and at the same time while he was ordering the heaven, he

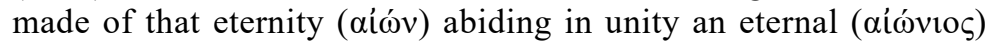
image moving according to number, that which, in fact, we have been calling time.For days and nights and months and years were not before the heaven came to be, but he made ready their generation then, simultaneously with the composition of time. Well, these are all parts of time, and that which was and that which will be are species of time that have come to be, and we without notic-

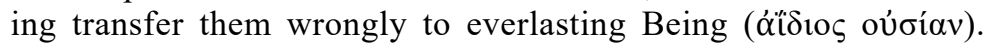
For we say that it was, is, and will be, but, according to the true account, only is is befitting for it, while was and will be is fittingly said of that Becoming passing through time - for these two are motions. On the other hand, it belongs not to that which is always

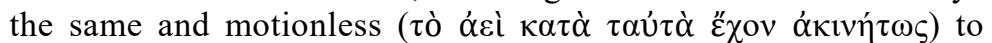
become neither older not younger with the passage of time, nor ever was so, nor has it now become so or hereafter will be; and not at all belong to it the characteristics which Becoming fastened to things that are born along in the world of sense, but they are generated forms of time, which imitates eternity ( $\alpha i \omega \omega v)$ and circles around according to number.

14 "For the duration which encompasses the timespan of each living thing... is called its aívv. Accordingly, the duration of the entire universe and the duration which encompasses all time and infinity is aívv." (De Caelo, 279a23-27).

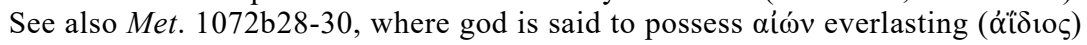

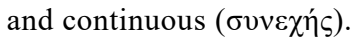

${ }^{15}$ According to Mohr (2005, p. 52), Plato is making a breakthrough in this case as well, by using $\alpha i \omega v$ "seemingly for the first time in (philosophical) Greek apparently as an abstract noun or mass noun ('eon-ity') rather than as a count noun (a life, an eon, a [very long] time)." 
On the terminological side, this excerpt is as messy as it can be. Plato here employs all the terms that were mentioned as somehow referring to the concept of eternity, regardless of how it is understood: we have the adverb ócí, the noun aínv, as well as the ad-

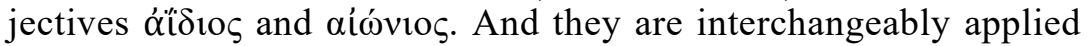
to entities that are supposed to be distinguished as eternal in the proper sense of the word on the one hand, and sempiternal on the other. To make things worse, two terms which should bear separate meanings are used to describe a single thing considered to be eternal. Thus, the gods are ótí $\delta 101(37 \mathrm{c} 6)$, but so is the Living Crea-

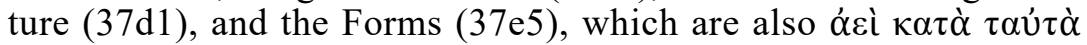
(38a3); the Living Creature is aí́viov (37d3), but so is also time (37d7). Hence it turns out that the Living Creature, which is a

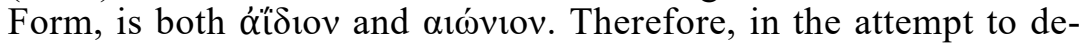
cipher this passage and understand Plato's concept of eternity one cannot rely on the ready-made solution offered by the Neoplatonist, who unanimously ascribed to aív $v$ the sense of atemporal

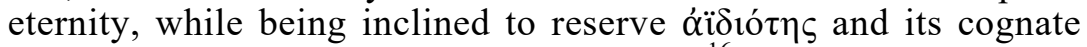
$\alpha$ át $\delta 10 \varsigma$ for everlastingness or sempiternity. ${ }^{16}$ As a matter of fact, the confused and confusing language present here goes in favor of Whittaker's thesis that Plato used the different eternity words in a single sense, and since, e.g. time is beyond doubt something durational, that alleged sense was much closer to what Boethius and other later philosophers and theologian would call sempiternity than to eternity proper. Nevertheless, the context within which those words are applied speaks out against Whittaker; the obvious confusion notwithstanding, from the statements made in the passage some clearly set out arguments can be deduced, and some important conclusions concerning Plato's understanding of eternity can be drawn.

Probably the first information that catches the eye of the above passage's reader is that time was created, that it came to be. Before the making of time, which coincides with the creation of the universe, there are no interchanging days, nights, months, years. This implies that even those who reject the literal interpretation of Timaeus' creation story have to accept that there is some state of affairs which subsisted prior to the emergence of time, some state of affairs, some existence, which, at least logically, preceded time. And if there is existence preceding time, it is only reasonable to maintain that such an existence must be timeless. That timeless existence is aíwv, or, keeping the original meaning of the word in

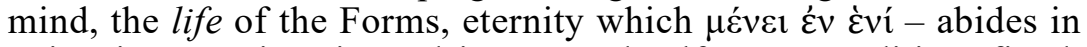
unity, i.e. remains situated in one and self-same condition, fixed, motionless, devoid of change. The conclusion that Plato recogni-

${ }^{16}$ See Wilberding, manuscript, p. 1. 
zes such a state is strengthened by the description of time as being always in motions, as circling through its forms of was and will be, and thus serving as propeller of change. For, time, the principle of change, which is never going to stop circling around ${ }^{17}$ is spoken of as the image of, and in this way is contrasted with, aíw , the changeless mode of existence characteristic of the Forms, themselves firm, unchangeable entities. In other words, Plato's Timaeus is here contrasting the ever-flowing everlastingness of time with the non-durational eternity, eternal unchanging present of aív. The former will never cease to be, but is moving and is divided into phases, and the things that have their lives in it are spoken of as something that was, is or will be; the latter, however, is immovable and fixed in one point, and the entities that have their life in it cannot be attributed with tensed expressions, but can be spoken only as Being. Theirs is the unchanging, durationless is of the timeless, eternal present. ${ }^{18}$ In this way, even while using painfully imprecise and inapt language, Plato draws a rather clear distinction between eternity and sempiternity. Therefore, despite the seemingly inexplicable terminological confusion, ${ }^{19}$ it may be rightly claimed that he was in possession of the concept of timeless eternity and that he usually used the word aív to express it. ${ }^{20}$ And as if to

${ }^{17}$ This is so because time was created along with the universe, and shall perish only if the universe perishes (38b6-6). But that will never be, since through-

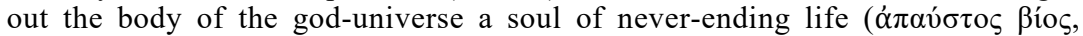
$36 \mathrm{e} 4$ ) is interwoven, a soul which will keep on rotating for all time (còv

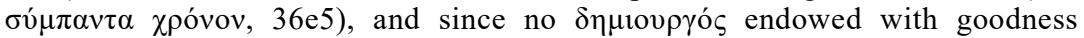
would destroy a structure as this universe is, so well-composed and beautiful

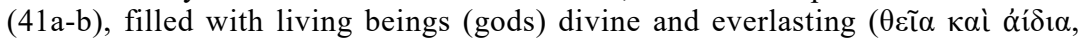
40b5).

18 A very beautiful explanation of the atemporal mode of eternity which manifest itself through the timeless present and the impossibility to associate tensed statements containing 'was' or 'will be' with it, is given by Plotinus in III.7.3.15-40.

19 It made Cornford (1997 (1937), p. 98, n. 1) propose emendation of the word 'eternal' ( $\alpha \dot{i} \omega$ vios), outrageously ascribed to everlasting time (37d7). Owen (1966, pp. 333f) offers the following solution to the difficulties of terminology: "What Plato says is that the physical world cannot be wholly or unqualifiedly eternal ... Plato means to recall those canonical arguments in the Phaedo and Republic which show that while things in this world can be beautiful or equal, large or single, they cannot be wholly or unqualifiedly so ... Similarly with the eternity of the physical world." For another, rather sophisticated explanation of the terminological puzzle, see Mohr 2005, especially pp. 66-68. His account, how-

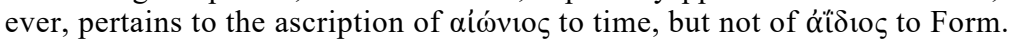

${ }^{20}$ Scholars have often tried to ascribe the 'discovery' of the concept of eternity to Parmenides, since in VIII. 5-6 he characterizes Being as follows: "Nor was it ever, nor will it be; for it is now, altogether, single, continuous" (Owen's translation (1966, p. 318)). Of this opinion are, e.g., W. Kneale (1960-1961, p. $87 \mathrm{ff}$ ), von Leyden 1964 , p. 36 , Митевски 2005 , p. 31 , fn. 12 , and especially 
pacify the skeptics, Plato decisively confirms this position in the closing sentence of the passage describing the creation of time: "For while the paradigm indeed exists for all eternity, the heaven has been, is and will be permanently throughout all time" ( $\tau$ ò $\mu \varepsilon \dot{v} v$

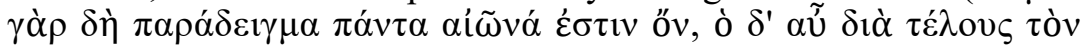

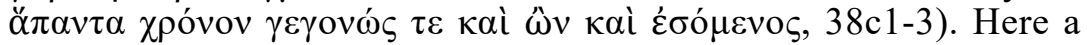
clear distinction is drawn between two modes of existence: one that is associated with the paradigm, i.e. the Forms, and the other that is associated with the created cosmos. The life of Being is eternity ( $\alpha i \omega v),{ }^{21}$ and it does not know of before and after, of ageing and change, while the life of Becoming is sempiternity, which knows of no end, but passes through various phases of was, is, and will be, throughout the infinity of time.

So much for eternity. When it comes to the nature of time and its place in the Timaean universe, so far only few things are clear: a) That it was generated, but will never cease to be; b) that it is an image resembling eternity to the degree that is possible, as much as the created cosmos is an image of the eternal Living Creature; c) that it is characterized by regular circular motion, in the course of which its aspects of was and will be emerge. Now, with a) and c) only some of the properties of time, as Plato understood it, are revealed, but not its essence, while the characterization of time as 'image of eternity' is seemingly too imprecise and poetic to disclose its real nature. All one can gather from the clause seems to be that time is in certain respect similar to, but nevertheless different from eternity. What is more, relatively recently a new strain of interpretation has appeared, one which actually denies that Plato ever thought of time as the image of eternity. It is argued for by Sallis (1999, pp. 78-84), who relies heavily on the investigations of the French philosopher Rémi Brague in his 1982 work Du temps chez Platon et Aristote: quatre étude. In Sallis' rendition, the sentence

Owen 1966, who provides a very detailed reconstruction and interpretation of Parmenides' argument. He adds: "It is Parmenides Plato is echoing ... in the Timaeus (37e-38a)" (1966, p. 327). For a criticism of Owen's position, see Tarán 1979, pp. 47ff. A broader exposition of the latter's view and listing of his other opponents is to be found in Tarán 1965, pp. 175ff. Wilberding, manuscript, pp. 37 gives a brief overview of the debate and sides with Tarán, offering some arguments for the view that Parmenides did not grasp eternity, but only everlastingness. For our purpose it is immaterial whether it was Parmenides or Plato who first came up with the concept of atemporal eternity. Our interest lays in showing that Plato knew it and made philosophical use of it.

${ }^{21}$ For the opinion that aív in Plato does not represent the mode of existence or life of Being, but stands for the Form of eternity, see Mohr 2005, p. 54. 
from which Plato's definition of time as the moving image of eternity is extracted (37d5-7), ${ }^{22}$ takes the following shape: "The thought occurred to him of making a moving image of eternity; and in ordering the heaven he makes the heaven as an image of the eternity that abides in unity, an image moving according to eternal number, that which we call time." 23 Thus Sallis, following Brague, claims that here both the verb $\delta 1 \alpha \kappa o \sigma \mu \varepsilon \dot{c} \omega$ (to set in order, regulate) and $\pi$ oté $\omega$ (make, create) have a single object, namely oúpavós (firmament, heavens, universe); subsequently, it is the heaven itself which was at the same time $(\ddot{\alpha} \mu \alpha)$ set in order and made into a moving image of eternity. The reading that setting the heaven in order and producing an image of eternity were two distinct creative act which took place simultaneously is simply wrong. But why is it wrong?

Sallis basically presents two reasons for that, and they will be dealt with only briefly here. Firstly, he presents an external reason, namely that the formula 'time is a moving image of eternity' had not be noted or commented upon by Plato's immediate successors, nay, not even until the era of the Middle-Platonists. However, although this could be a cause for concern, let us mention that Speusippus, Xenocrates, Crantor, etc., all believed that the act of creation in the Timaeus was to be understood metaphorically; but that does not mean that this was necessarily also Plato's stance, as the ongoing debate on the issue demonstrates. Besides, they are entitled to hold views different from their great predecessor's, as they indeed held, and even on some quite crucial matters. Finally, even if the preserved opinions of Plato's immediate heirs were taken as representing the proper Platonic outlook on the essence of time, they a) simply do not consider the simile of the image, neither in the traditional, nor in Sallis' sense; and b) do not support Sallis' overall understanding of time in the Timaeus, but mostly bring it in connection with the motion of the heavenly bodies or with motion itself. $^{24}$

Secondly, an internal, and accordingly more important, reason is given: "Several features of the passage itself make one hesitant to replace it [the reformed reading] with the traditional formu1a." ${ }^{25}$ Unfortunately, the reader is not told much about those features. All one gets is the claim that the proposed retranslation / rein-

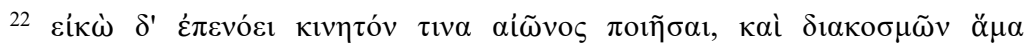

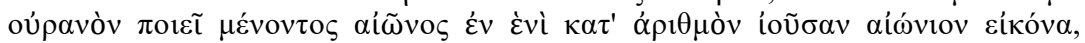

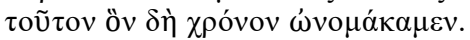

${ }^{23}$ Sallis 1999 , p. 78

${ }^{24}$ The opinions of Xenocrates, Histiaeus and Speusippus are quoted in Taylor 1928, pp. 190f.

${ }^{25}$ Sallis 1999 , p. 78 
terpretation constitutes "a more natural construal... of the passage," supported by a quotation from Brague's book. ${ }^{26}$

Now, Brague there argues against the traditional reading on purely linguistic grounds - the construction present participle-adverb-

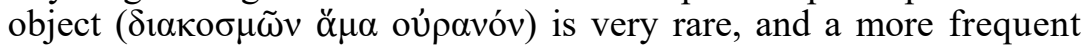
and natural construal would be the adverb following a participle used absolutely, after which the 'normal' object-verb order is set

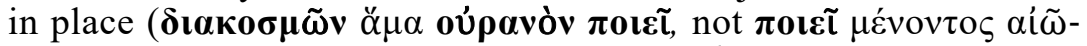

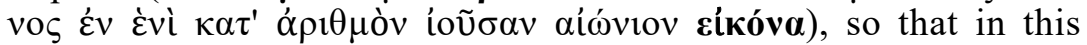
way oúpavó remains the direct object of both the participle and the finite verb. ${ }^{27}$ But this is, of course, no proof of the veracity of Brague's position, since, as acknowledged also by himself, the traditional construal does not in the slightest violate the rules of grammar. Besides, it seems that Brague reaches a bit too far in asking for linguistic puritanism in a dialogue notorious for its difficult language, and even in a passage where Plato uses a neologism of his own making - the adjective aíwvıs. As for Sallis, he further supports the novel reading represented by his own translation with the following statement: "Not only does this construal tend to break down the mutual distinctness of the two activities, but also it indicates that what the god makes is the heaven and not some image distinct from the heaven, not a distinct image that would then be identified as time." 28

This is, however, problematic in a rather obvious way. Namely, it is not intuitively or demonstratively clear that it is intrinsically good or even desirable to direct the two activities of ordering and making to a single object, i.e. the heaven - the necessity of such a step arises only when the alternative reading is presupposed to be the right one. Sallis' argumentation is thus a case of the petitio principii fallacy, since it already assumes the very conclusion that has to be proven.

Besides these challenges that the new interpretation should meet in order to gain solid ground, there are also some positive indication in the Timaeus which go in favor of the traditional reading. First, the cosmos, including the stars and the planets - the visible gods (i.e. the starry heaven, or oúpavós in the restricted sense

${ }^{26}$ Op. cit., p. 79 , n. 48

${ }^{27}$ Cleve (1950, p. 192) is also convinced that the thing which was made into an image of eternity was the "world of celestial bodies", i.e. the heaven. His rationale is somewhat different, though: he holds that $\delta 1 \alpha \kappa o \sigma \mu \tilde{\omega} v$ needs no objects

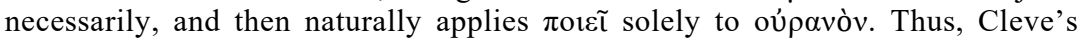
rendering reads: "[w]hen building up the world $(\delta i \alpha \kappa o \sigma \mu \tilde{\omega} v)$ he simultaneously makes heaven a numerically ( $\left.\kappa \alpha \tau^{\prime} \alpha \rho \rho \jmath \mu o ̀ v\right)$ proceeding, eternal ... image of in oneness staying eternity."

${ }^{28}$ Op. cit, p. 80 
of the word), is repeatedly declared to be an image of the eternal Living Creature (30c-31a, 37d, 39e-40a, 41b-c, etc.); so it is hardly possible that Plato would suddenly change his opinion and proclaim the oúpavó $\varsigma$ to be an image of eternity instead. Second, while Sallis writes: "Indeed, the adverb ö $\mu \alpha$ (at once, at the same time) suggests that the god's ordering of the heaven is the very same deed as that by which he makes the heaven as an image of eternity" 29 , only few lines later in the text one finds a confirmation of the traditional reading, which understood the adverb as expressing simultaneity of two actions - the ordering of the oúpavós and the making of $\chi \rho$ óvos: "And thus, time has come to be together with heaven ( $\mu \varepsilon \tau^{\prime}$ oú $\left.\rho \alpha v o \tilde{u}\right)$, in order that having been begotten together [at the same time, $\alpha_{\alpha} \mu \alpha$ ], they may also perish together $(\check{\alpha} \mu \alpha)$, if ever dissolution of them takes place" (38b6-7). In this statement, as well as in the whole passage $38 \mathrm{~b} 6-\mathrm{c} 3$, time is clearly distinguished from the heaven, as something which was generated at the same time with it, but is not identical with it. Time is here once again evoked as a feature of the oúpavós - and thus distinct from the latter - which helps to make it as similar to the divine paradigm as possible. Similarly, third, at 37d7, 38a7-8, 38b9-c3 Plato says that the thing which moves around in a circle according to

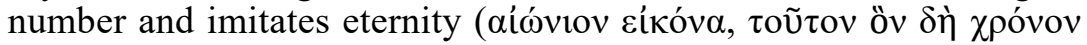

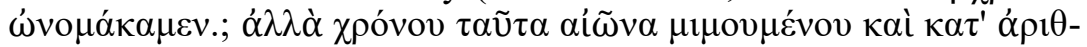
$\mu$ òv, etc.) is time, and not heaven; had he intended to make time and the heaven synonyms, and had he wanted us to believe that was and will be are parts of the heaven, wouldn't he clarify and emphasize that difficult point by clearly stating, at least once, that it is the heaven which imitates eternity? Fourth, although Sallis' language is a bit ambiguous on this point, he seems to hold that time is not the motion of the heavenly sphere, as one would expect, ${ }^{30}$ but that it is the heaven itself set in motion; at the end of the passage where he establishes the identity of time and the sphere, Sallis writes, using italics for emphasis, that time is "heaven-moving-accordingto-number." ${ }^{\prime 3}$ One of the problem with this proposal is that the heavenly sphere includes both the fixed stars and the 'wanderers' - or the planets - which are situated on the circle of the Same and the Different respectively. Now, since the circles of the Same and the Different revolve in opposite directions (36b-d), if time is the oúpavós in motion, then the circular motion of time will not be uniform, i.e. there will be at least two times moving in two different directions. As a matter of fact, the view that time is the sphere

${ }^{29}$ Ibid.

${ }^{30}$ Which is one of the three ancient attempts to explain time, listed and refuted by Aristotle in his Physics 218a30-218b20. It is also mentioned by Plotinus in Enn. III.7.7.23, and refuted in III.7.8.

${ }^{31}$ Sallis 1999 , p. 82. 
itself was one of the traditional accounts of time. Aristotle mentions it as such in the Physics 218b6-9, but dismisses it without much comment, considering this view as too naive to be worth of serious refutation. ${ }^{32}$ Aristotle was a sharp critic of Plato, but never

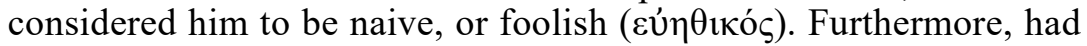
there been any indications that this was the theory actually held by Plato (and Aristotle of course had great chances to be aware of that), he would not have missed the chance to point out that Plato, or those around him, were associated with this incredible view.

From all this one can gather that the Platonist, starting at least from Alcionus ( $2^{\text {nd }}$ century $\left.A D\right)$, have been justified in referring to time as to the moving image of eternity, and that this image of eternity is not identical with the starry heaven. Nevertheless, the question 'what is time for Plato?' remains barely answered. As a reminder, in the original definition Plato described time as follows: "[the Demiurge] makes of that eternity abiding in unity an eternal image moving according to number, that which, in fact, we

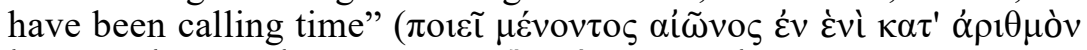

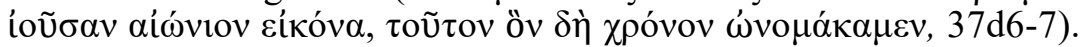
Now, Zeyl in his translation of the dialogue, as well as Johansen in his study of the Timaeus-Critias (2004, p. 58) justifiably supply the word 'number' after the demonstrative pronoun oũ $\tau$ s, and thus have the last clause read: "This number, of course, is what we now call time." ${ }^{33}$ It seems that with this step, taken at its face value, Zeyl and Johansen effectively equate time with number. ${ }^{34}$ But that is hardly right. First, the context of the passage makes it clear that what the Demiurge produces is a moving cíkóv, whose motions proceed according to number, i.e. regularly, while from here as well as from the aforementioned $38 \mathrm{a} 7-8$ and $38 \mathrm{~b} 9-\mathrm{c} 3$ it is obvious

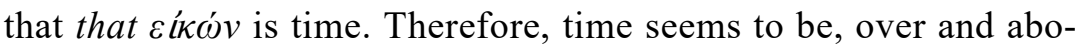
ve all, that particular image in motion, although it is not yet clear what is that supposed to mean. It can perhaps be called number only derivatively, i.e. in the sense that time is something countable,

${ }^{32}$ Simplicius ascribes it to the Pythagoreans (see von Leyden 1964, p. 48), and Pseudo-Plutarch to Pythagoras (Placita Philosophorum 884B4). The theory of time as the heavenly sphere (in motion) is recognized by Plotinus as well (III.7.7.24). He deals with it very briefly, in a single sentence (III.7.8.20-22).

${ }^{33}$ This is Zeyl's version. Johansen has: "This is the number, indeed, which we have called time."

${ }^{34}$ As a matter of fact, Johansen does not elaborate on this point (ibid.), while Zeyl is also far from explicit in his Introduction to the Timaeus (pp. xliixliii). Nevertheless, it is obvious that considerations of grammatical nature prompted them to offer such rendition: the masculine demonstrative and relative pronoun can be construed only with the preceding $\alpha \rho p \theta \mu$ ó $\zeta$, although it is a part of the adjectival phrase $\kappa \alpha \tau^{\prime} \alpha \dot{\alpha} \rho t \theta \mu$ òv ioṽ $\sigma \alpha \nu$. The same point is brought out by Mohr (2005, p. 56, fn. 12). 
on account of the regular motions of its indicators, the planets, which mark the divisions of time into days, months, years, i.e., into numbers of time. ${ }^{35}$ Second, the definition of time as number belongs to Aristotle, who says: "Time is, then, some kind of number" (Phys. 219b5) - not as a number with which we count, but as something countable, or better, as measure. Not unlike Plato, he brings time in close relation with motion, ${ }^{36}$ and so explains time more precisely as "number of motion with respect to before and after" (Phys. 219b2). ${ }^{37}$ Glossed by one modern commentator, Aristotle's vision of time in a nutshell reads: "[t]ime is neither motion nor a quantity of motion ... but that in respect of which motion can be counted." 38 And again, had Plato seriously made any steps toward describing time as number, Aristotle, as an honest intellectual, would have mentioned it as one of his predecessors' theories, or would have acknowledged his debt, and Plotinus would not have so severely attacked the same position (in Enn. III.7.9).

But what, then, is time for Plato? If it is not the heavenly sphere, and not number, is it perhaps the motion of the whole ( $\tau \dot{\eta} v$

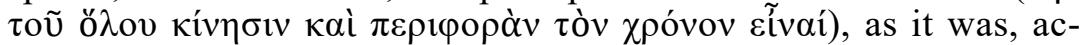
cording to Simplicius, asserted by Theophrastus, Eudemus and Alexander? ${ }^{39}$ The main problem with this definition is that it is nowhere to be found in the Timaeus, although some later doxographers cite it as representing Plato's view on the nature of time. ${ }^{40}$ Plotinus certainly does not take it as having anything to do with

${ }^{35}$ I would even suggest that an early corruption that entered our manuscripts should not be ruled out completely.

${ }^{36}$ At the same time denying that it should be identified with any kind of cosmic motion or with motion per se, i.e. with movement independent of the heavenly revolution, or with any property of motion (Phys. 218a30-218b20).

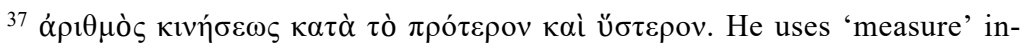

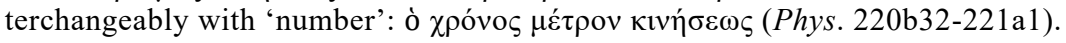

38 von Leyden 1964, p. 49. Aristotle' detailed theory of time is to be found in the Physics IV. 11-14. Very close to his definition are those of the Platonic

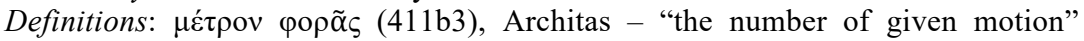
(Clark, 1944, p. 338), Zeno - "interval, extension ( $\delta$ ió $\sigma \tau \eta \mu \alpha)$ of motion" (SVF I.96), and Chrysippus - "concomitant interval of the motion of the world" (SVF II. 509.3-4). It is interesting to note that the Middle-Platonist Alcinous (mistakenly) presents as Plato's a definition almost identical with the latter, together with the 'image of eternity' simile (see Dillon 1993, p. 24). He seems to be followed almost literally by Pseudo-Plutarch (Placit. 884B5), who gives both Alcinous' definitions as Plato's: time is a moving image of eternity, or an interval of the motion of the cosmos.

39 Theophrastus apud Simplicius, Physicorum opiniones, fr. 15.1. Aristotle and Plotinus both cite this position, without identifying its proponent (see supra, fn. 30).

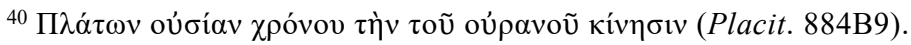


Plato (Enn. III.7.7), and a number of modern scholars are quite critical of it. ${ }^{41}$ Of course, it is hard to escape the impression that Plato conceived of time as somehow identifiable with motion, however not with whole motion or motion in general, ${ }^{42}$ nor with the interval or the distance covered by it, ${ }^{43}$ but with motion of some important parts of the whole, i.e. the planets. This is so because in the text of the Timaeus, as transmitted to the English reader, one can find some indications that he believed exactly that. For example, Zeyl translates 38c3-6 as follows: "Such was the reason, then, such the god's design for the coming to be of time, that he brought into being the Sun, Moon and the five other stars, for the begetting of time." 44 A bit later, Cornford has: "when each one of the beings that were to join in producing Time [i.e. the planets] had come into the motion suitable to it..."45 (38e3-5), as well as "They [men] barely know that the wanderings of these others [i.e. the planets other that the Sun and the Moon] are time at all, bewildering as they are in numbers..."46 (39d1-2). Probably having these and similar statements in mind, Taylor also writes: "It seems to me... that the language of the Timaeus plainly identifies time with the uniform movement of a planet." 47

This impression, however, need not be right. In the first instance, Zeyl's translation might be slightly misleading. It is not that the Demiurge brought the planets into being for the begetting of time; he did so in order that they may divide and preserve the

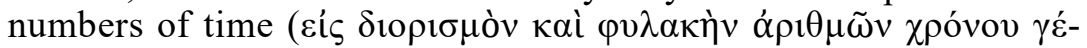
yovev, 38c6), in accordance with his previous plan to generate it. The planets are, of course, instrumental factors in begetting time, since without them its number, or measure, cannot be determined, but their revolutions are nevertheless not identical with it. As far as the first quotation of Cornford's translation is concerned, the word which he renders with "to join in producing" ( $\sigma v v \alpha \pi \varepsilon \rho \gamma \alpha \dot{\zeta} \varepsilon \varepsilon \sigma-$ $\theta \alpha 1)$, actually has the lexical definition "to help in finishing or com-

41 "And if the mention of the definition of time as the revolution of heavens were intended as indication of what Plato says in the Timaeus, it would be a gross misrepresentation" (Rau 1953, pp. 515f); "The attribution in question ... rests on misunderstanding of Timaeus 39b-d and other passages" (von Leyden 1964, p. 48); "Such representation, however, does Plato scant justice" (Clark 1944, p. p. 337).

42 Which was the theory of some of the Stoics (see SVF II.514).

${ }^{43}$ As time was understood by Zeno and Chrysippus.

${ }^{44}$ Zeyl 2000, p., emphasis added.

${ }^{45}$ Cornford 1997 (1937), p. 112, emphasis added.

${ }^{46}$ Op. cit., p. 116, emphasis added.

47 Taylor 1928, p. 191. 
pleting. ${ }^{48}$ So, if one preserves the primary meaning of the term, then the sentence acquires rather weaker sense. Now the planets do not join anymore in order to produce time, but only to help in completing the process of producing it, and this they do, I recon, by providing a perceptible measure of its flow. In Cornford's second quotation, Plato is not using precise philosophical language, but a figure of speech, like when one says "I'm running out of time", pointing to his or her hand watch. Neither Plato nor our speaker believe that the planets (which comprise the celestial clock) or the hand-watch are identifiable with time - they just use a convenient and elegant way to express certain ideas. ${ }^{49}$ Had Plato seriously believed that the movements of Venus, Mercury, Mars, Jupiter and Saturn (besides the Sun and the Moon) are really time, he would have been a proponent of a multiple time-system theory, since the 'wanderings' of all these planets are diverse, and thus each of them would produce a different time. ${ }^{50}$ However, such theory is unheard of in the Ancient world, and there is scant probability that it would have pass unnoticed, had Plato indeed propounded it. What the $\pi \lambda \alpha ́ v \eta \tau \varepsilon \varsigma$ actually do is providing different standards of measurement of time. ${ }^{51}$ So the planets and their revolutions have been created in order to divide and preserve the numbers of time $(38 \mathrm{c} 6)$, i.e. to serve as a kind of complex device for measuring time, and not in order to generate it. ${ }^{52}$

${ }^{48} \alpha \pi \varepsilon \rho \gamma \alpha \dot{\zeta} \varepsilon \sigma \theta \alpha 1$ also does not mean 'to produce'.

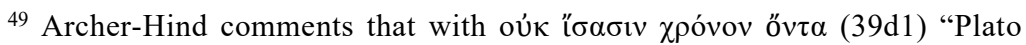
means that men have not generalized concerning time: they do not reflect that the revolutions of the other celestial bodies equally afford measurement of time" (1888, p. 129, emphasis added).

Similarly Taylor 1928, p. 215. But $c f$. Cornford 1997 (1937), p. 103, where he speaks of time as produced by the celestial revolutions. Nevertheless, he also might not meant this statement to be understood literally, because he has the word 'produced' put in inverted commas.

${ }^{50}$ Similarly like in the aforementioned case of the contrary motions of the circles of Same and Different (p. 11).

${ }^{51}$ In this sense one may say that the fixed stars 'produce' night and day, the Moon produces the month, the Sun the year, and the others measure some other periods, but they are too complex and impractical to attract the attention of an ordinary human being. The most basic measurement is the alternation of night and day, which is due to the motion of the circle of the Same, and which provides the fundament for the human capacity of understanding and applying number $(39 b-d)$.

52 Thus also Archer-Hind: "And for the measuring of time God made the sun and the moon and five other planets" (1888, p. 122, emphasis added). For further argument against the notion that the planets' motions constitute time, although unrelated to the Platonic debate, see St. Augustine's Confessions XI.23.26. In

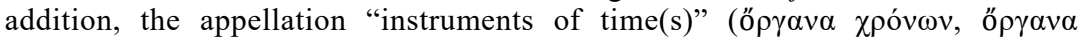

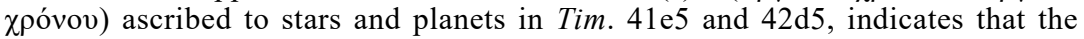


Of course, time is inseparable from motion, although not because it is motion, but because it is in motion, as Plato rather explicitly states at $37 \mathrm{~d} 5-7,38 \mathrm{a} 7-8$ - time is the subject which is characterized by, or has motion as its attribute, the latter being not random or erratic, but according to number, i.e. regular. ${ }^{53}$ Regular and uniform motion is essential property of time, ${ }^{54}$ because time cannot be what it is without being in motion, without passing through the phases of before and later, of was and will be. Motion is for Plato also inseparable from soul, ${ }^{55}$ the principle that gives life to the world of Becoming, which is recognizable through a constant, never-ending succession of events. Now, this ethereal notion of life of the universe is, in my opinion, the closest possible articulation of Plato's concept of time in the Timaeus. In light of this un-

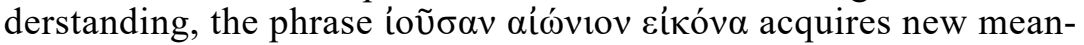
ing, and gains much greater weight. It is not anymore just a metaphorical expression, a poetic picture with little philosophical background, but conveys a deep Platonic truth about the essence of time (as also confirmed by Plotinus, (III.7.13.24-25)). As it was already mentioned, the nature of the Intelligible world is to exist in a state of eternity, to have - figuratively speaking - life eternal, which is devoid of motion and always established in oneness. This

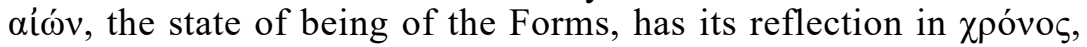
which is there in order to make the world of Becoming as exact a replica of the world of Being as possible, by providing it with never-ending life. However, since it is only an image, time imitates eternity imperfectly, and this imperfection is conspicuous through its constant motion, which entails permanent change and instability. Time, the sempiternal life of the universe, is in this way distinguished from motionless eternity as having much lower ontic status. It flows incessantly, going through the periods of nights and days, months and years - which are measured by the positions of the heavenly bodies ${ }^{56}$ - carrying in its stream the successive chan-

heavenly bodies are not producers of time, but serve some other (i.e. measuring) function in connection with it.

${ }^{53}$ For a thorough Platonic rebuttal of the thesis that time is motion, be it independent one or the motion of the sphere, see Plotinus' Enn. III.7.8, and the analysis of the arguments in Clark 1944, pp. 337-342.

${ }^{54}$ This is another reason why the movement of the planets cannot be time: their revolutions are regular, but not uniform; what is more, Mars, Jupiter and Saturn also possess the power of counter-revolution, with respect to the circuit of the Different, while as for time - even if one takes the reversal of time in the Politicus myth seriously - it is impossible to simultaneously flow in two directions.

${ }^{55}$ See Phaedrus 245e2-246a2; Laws 895c-896a.

${ }^{56}$ The full cosmic period, marked by the return of all heavenly bodies to the common imaginary starting point, is called the Great Year. For elucidation of this concept, see Dillon 1993, p. 130, and Taylor 1928, pp. 216-219. 
ges of events, because such is the nature of the sensible world: to be extended both spatially and temporally. Therefore, time is for Plato most accurately defined as "image of eternity", in the same way as "the created god", the cosmos, is properly called an image of the divine paradigm. The changeless, non-spatial Form of the Living Creature is reflected as the physical world of our experience, and its state of being, the motionless eternity, is reflected as time, which is the state of being or life of the universe. ${ }^{57}$

\section{BIBLIOGRAPHY}

Archer-Hind 1888: Archer-Hind, R. D.: The Timaeus of Plato: Edited with Introduction and Notes. London: Macmillan and Co., 1888

Shedd 1867: Augustine.: Confessions. In Shedd, W. G. T. (ed.) Boston: Darper and Halliday, 1867

Watts 1969: Boethius.: The Consolation of Philosophy. In Watts, W. E. (tr.) Harmondsworth: Penguin Books, 1969

Cherniss 1944: Cherniss, H.: Aristotle's Criticism of Plato and the Academy. Baltimore: Johns Hopkins Press, 1944

Clark 1944: Clark, G. H.: "The Theory of Time in Plotinus". The Philosophical Review 53.4. (1944): 337-358

Cleve 1950: Cleve, F. M.: "Review of Four Views of Time in Ancient Philosophy by Callahan, John F. Cambridge: Harvard University Press, 1948”. Classical Philology 45. 3. (1950): 191-194

Cornford 1997: Cornford, F. M.: Plato's Cosmology: The Timaeus of Plato. Indianapolis: Hackett Publishing Company, 1997 (1937).

Dillon 1993: Dillon, J.: Alcinous: The Handbook of Platonism, Translated with Introduction and Commentary. Oxford: Oxford University Press, 1993

Helm 2014: Helm, P.: "Eternity." The Stanford Encyclopedia of Philosophy (Spring 2014 Edition), Edward N. Zalta (ed.), URL = $<$ http://plato.stanford.edu/archives/spr2014/entries/eternity/>.

Johansen 2004: Johansen, T. K.: Plato's Natural Philosophy: A Study of the Timaeus-Critias. Cambridge: Cambridge University Press, 2004

Kneale 1968-1969: Kneale, M.: "Eternity and Sempiternity." Proceedings of the Aristotelian Society 69. (1968-1969): 223-238

Kneale 1960-1961: Kneale, W.: "Time and Eternity in Theology." Proceedings of the Aristotelian Society 61. (1960-1961): 87-108

57 This view on Plato's concept of time is aligned to Plotinus' interpretation of the Platonic position, as expressed in III.7.11, and elaborated on in III.7.1213 , in as much as Plotinus also perceives time as an image of eternity, which is life perfect (III.7.11.40-50). For a very different turn on the issues of time and eternity in Plato see Mohr 2005, where both categories are interpreted from a primarily epistemic, and thus anthropocentric standpoint. 
LSJ: Liddell, H. G., Scot, R. and Jones, H. S. A Greek-English Lexicon, $9^{\text {th }}$ edition with supplement. Oxford: Oxford University Press, 1996

Митевски 2005: Митевски, В. (tr.).: Платон: Тимај. Скопје: Аз-Буки, 2005

Mohr 2005: Mohr, R. D.: God and Forms in Plato. Las Vegas: Parmenides Publishing, 2005

O’Neill 1962: O’Neill, W.: “Time and Eternity in Proclus.” Phronesis 7.2. (1962): $161-165$

Onians 1951: Onians, R. B.: The Origins of European Thought about the Body, the Mind, the Soul, the World, Time and Fate. Cambridge: Cambridge University Press, 1951

Owen 1966: Owen, G. E. L.: "Plato and Parmenides on the Timeless Present." The Monist 50. 3. (1966): 317-340

Rau 1953: Rau, C.: "Theories of Time in Ancient Philosophy." The Philosophical Review 62.4 (1953): 514-525

Rogers 1994: Rogers, K.: "Eternity has no Duration.” Religious Studies 30. 1. (1994): $1-16$

Sallis 1999: Sallis, J.: Chorology: On Beginning in Plato's Timaeus. Bloomington: Indiana University Press, 1999.

Sorabju 1983: Sorabji, R.: Time, Creation and the Continuum: Theories in Antiquity and the Early Middle Ages. London: Duckworth, 1983

Tarán 1965: Tarán, L.: Parmenides: A Text with Translation, Commentary and Critical Essays. Princeton: Princeton University Press, 1965

Tarán 1979: Tarán, L.: "Perpetual Duration and Atemporal Eternity in Parmenides and Plato." The Monist 62. 1. (1979): 43-53

Taylor 1928: Taylor, A. E.: A Commentary on Plato's Timaeus. Oxford: Clarendon Press, 1928

von Leyden 1964: von Leyden, W.: "Time, Number and Eternity in Plato and Aristotle." The Philosophical Quarterly 14. 54 (1964): 35-52

Wear 2008: Wear, S. K.: "Syrianus the Platonist on Eternity and Time." The Classical Quarterly 58. 2. (2008): 648-660

Whittaker 1968: Whittaker, John.: "The "Eternity" of the Platonic Forms." Phronesis 13. 2. (1968): 131-134

Wilberding manuscript: Wilberding, J.: "Eternity in Ancient Philosophy". Forthcoming in Eternity. Oxford Philosophical Concepts Series. Ed. Melamed, Y. Oxford: Oxford University Press.

Zeyl 2000: Zeyl, D. (tr.).: Plato: Timaeus. Indianapolis: Hackett Publishing Company, 2000. 